JP3I (Jurnal Pengukuran Psikologi dan Pendidikan Indonesia), 9(2), 2020, 44-56

D0l: http://dx.doi.org/I0.15408/p33iv9i2.XXXXX

http://journal.uinjkt.ac.id/index.php/jp3i

\title{
Female Hedonistic Behavior Questionnaire (FHBQ): Psychometric Properties Based on the Rasch model
}

\author{
Tina Deviana, Bahrul Hayat, Nia Tresniasari \\ Faculty of Psychology, UIN Syarif Hidayatullah Jakarta, Indonesia \\ tinadeviana22@gmail.com
}

\begin{abstract}
This study aims to develop standard measurement tools from hedonistic behavior using the perspective of the Rasch measurement model. The evaluation of psychometric characteristics conducted in this study (1) to check unidimensionality, (2) testing local independence assumptions, (3) testing scale rating diagnostics, (4) testing item fit, (5) reliability for person and items, and (6) displays the wright map and test information function to compare people and items on the same scale and find out the functioning of the test when given to individuals with the level of trait obtained. The sample in this study were 335 hijabwearing Muslim women. Rasch analysis results show that the psychometric characteristics obtained are very good and precise, as well as the suitability of the items to the model. With this, the measuring instrument developed by researchers was named the Female Hedonistic Behavior Scale (FHBQ) with 14 valid items from the Rasch rating scale model from the measurement model perspective.
\end{abstract}

Keywords: hedonistic behavior, validation, Rasch model. 


\section{Introduction}

Hedonism is defined as any theory that suggests that pleasure and the avoidance of pain are the only or major motivating forces in human behavior (VandenBos, 2015). The term hedon' is often used in daily life, especially by the millennial generation. Generally, hedon' refers to describe the behavior of wasting money. In psychological research, there are quite a number of terms that can be used to describe this behavior, such as impulsive buying, consumptive behavior, or the terms hedonic, hedonism and hedonistic. These various terms describe the same thing, namely when pleasure becomes one's main orientation (Higgins, 1997).

Within the last decade, the concept of hedonism has generated a great deal research interest in the areas of social sciences. If the term hedon is used without ignoring other terms (i.e., impulsive buying or consumptive behavior), there are various studies using the term hedon, such as hedonistic behavior (Hamzah et al., 2014), hedonic orientation (Teo \& Sidin, 2014), and hedonic lifestyle (Kunzmann, Stange, \& Jordan, 2005). The use of this term provides various advantages, such as no longer using other dimensions outside of research on hedonism. In order to maintain consistencies, in the present study, we used the term hedonistic behavior, consistently.

Hedonistic behavior is often studied on women (e.g., Teo \& Sidin, 2014). The interesting thing is when the women samples are Muslims. Previous research has found that how hijab women express themselves indirectly leads to hedonistic behavior (Gulamhussein \& Eaton, 2015; Rofhani, 2017). This is closely related to the appearance of modern young Muslim women in line with the development of the Muslim fashion industry. In fact, there are Islamic teachings that should be able to interpret hijab as a form of obedience and obedience to a person, not showing hedonistic behavior seeing oneself only for social status (Gulamhussein \& Eaton, 2015).

Previous research on the study of measuring hedonistic behavior such as the Hedonism Scale (SobolKwapinska, 2013), Female Hedonic Orientation Scale (FHOS; Teo \& Sidin, 2014), and Orientation to Happiness Scale (Peterson, Park, \& Seligman, 2005). The three measuring instruments are measuring instruments developed specifically in the perspective of psychology, so that their use is limited by the various definitions of the term hedonistic.

In general, hedonistic behavior is an attitude and behavior that arises or arises from hedonism (Hamzah et al., 2014). In this study, the concept of hedonistic behavior derived from three aspects of the hedonistic lifestyle from Wells and Tigert (1971), namely: interest, activity, and opinion. The aspect of interest is defined as an individual's interest in what is in his environment. The activity aspect is an individual's way of using time that is tangible action which can be seen from the pleasures of life. The opinion aspect is an individual opinion given in response to situations when statements arise or about social issues, and products related to a person's hedonistic behavior (Wells \& Tigert, 1971).

In Indonesia, most researchers (e.g., Saputri \& Rachmatan, 2016; Sholeh, 2017) have used 3 (three) aspects of the hedonistic lifestyle of Wells and Tigert (1971) to measure and studying hedonism or hedonistic behavior, but the instruments for measuring hedonistic behavior has not been developed, especially for hijab-wearing Muslim women. Likewise, in the psychometric evaluation of the 3 (three) aspects of the hedonistic behavior referred to, most researchers do not yet know that there is a methodological approach that is more modern than the classical test theory approach which is still used today.

Therefore, this study aims to develop an instrument for measuring the hedonistic behavior construct (Hamzah et al., 2014; Wells \& Tigert, 1971). This instrument was analysed using modern test theory, which is Rasch measurement model. The evaluation of psychometric characteristics is carried out in this study (1) checking construct unidimensionality, (2) local independence testing, (3) rating scale diagnostics, (4) item 
fit-statistics, (5) reliability for person and items, and (6) graphical representation using a wright map and a test information function to compare people and items on the same scale and find out the function of the test when given to individuals with the level of traits obtained. Meanwhile, the results of the evaluation of psychometric characteristics will obtain the accuracy of the model along with a set of fit items describing hedonistic behavior which is theorized from a measurement model perspective.

\section{Methods}

\section{Participants}

Participants were 335 Indonesian female Muslim students with an age range 17-25 years (mean = 19.84 years, $\mathrm{SD}=1.38$ ) who came from nine faculties at Syarif Hidayatullah State Islamic University Jakarta. The sampling technique used in this study is the nonprobability sampling method. This method is used because the authors do not know for sure the size of the population that meets the criteria in this study, so that the preparation of a sampling frame as a requirement of probability sampling was not possible. Data colletion was carried out directly by the author to the person that meet the criteria of purposive sampling in the population and research samples that had been determined.

\section{Instrument}

In this study, an instrument to measure hedonistic behavior was developed derived from three aspects of the concepts of AIO (activity, interest, and opinions) coined by Wells and Tigert (1971). Initial scale development involved consideration of the aims and purpose of the measure, the theoretical constructs to be covered, the format and readability of items and the response format to be used. Although there are three aspects, since the beginning of its development, this instrument was theorized to be bipolar (lessmore), where more indicates high hedonistic behavior and less describes low hedonistic behavior. Therefore, 14 items are theorized to measure hedonistic behavior. We named this instrument as the Female Hedonistic Behavior Questionnaire (FHBQ).

Table 1. Blueprints of FHBQ

\begin{tabular}{|c|c|c|c|c|}
\hline No & Aspect & Indicators & No. Item & $\begin{array}{c}\text { Number of } \\
\text { Items }\end{array}$ \\
\hline 1 & Interests & $\begin{array}{l}\text { - Have an interest in fashion } \\
\text { - Have an affinity for food } \\
\text { - Have an affinity for luxury objects } \\
\text { - Have an interest in gathering places } \\
\text { - Have a desire to always be the center of attention }\end{array}$ & $1,2,3,4,5,6$ & 6 \\
\hline 2 & Activities & $\begin{array}{l}\text { - Enjoys spending time outdoors } \\
\text { - Happy to buy things that are not needed } \\
\text { - Go to shopping malls and cafes }\end{array}$ & $\begin{array}{l}7,8,9 \\
10,11\end{array}$ & 5 \\
\hline 3 & Opinions & $\begin{array}{l}\text { - Life pleasure response is important } \\
\text { - It's okay to spend a lot of money on fun things }\end{array}$ & $\begin{array}{c}12,13 \\
14\end{array}$ & 3 \\
\hline & & Number of items & & 14 \\
\hline
\end{tabular}

The 14-item FHBQ was included in the questionnaire completed by hijab-wearing female Muslim students who took part in the paper-pencil survey study. Participants were asked to rate each statement on the FHBQ on a 4-point Likert scale ranging from 1 (strongly disagree) to 4 (strongly agree). The blueprint of the three subscales of hedonistic behavior can be seen in Table 1, and the full item wording of 14-items FHBQ in Table 2. 
Table 2. Item Wording of the 14-Items FHBQ

\begin{tabular}{|c|c|}
\hline No. & Item Wording \\
\hline 1. & Saya tertarik untuk memiliki barang-barang mewah. \\
\hline 2. & Saya senang menjadi pusat perhatian. \\
\hline 3. & Saya selalu ingin bersenang-senang dengan teman-teman. \\
\hline 4. & Saya tertarik pergi ke tempat yang belum saya kunjungi untuk bersenang-senang. \\
\hline 5. & Saya tertarik membeli pakaian baru disetiap situasi/acara untuk dilihat orang lain. \\
\hline 6. & $\begin{array}{l}\text { Saya tertarik pergi ke tempat makan yang belum pernah saya datangi untuk bersenang- } \\
\text { senang. }\end{array}$ \\
\hline 7. & Saya sering membeli barang-barang yang kurang bermanfaat. \\
\hline 8. & Saya banyak menghabiskan waktu ke pusat pembelanjaan. \\
\hline 9. & Saya seringkali pergi ke café untuk menghabiskan waktu bersama teman-teman. \\
\hline 10. & Saya lupa waktu ketika berbelanja. \\
\hline 11. & Saya sering menghabiskan waktu dan uang untuk bersenang-senang dengan teman-teman. \\
\hline 12. & Kesenangan dalam hidup adalah hal yang terpenting. \\
\hline 13. & $\begin{array}{l}\text { Tidak masalah ketika mengeluarkan uang lebih banyak untuk membeli barang yang saya } \\
\text { sukai. }\end{array}$ \\
\hline 14. & Saya menghabiskan uang yang saya miliki hanya untuk bersenang-senang. \\
\hline
\end{tabular}

\section{Confirmatory Factor Analysis (CFA)}

The CFA model determines how the observed variables are related to latent variables. CFA is one type of structural equation model and provides a powerful method for testing various hypotheses about a set of measured variables (Flora \& Curran, 2004). In this study, the factor structure of the FHBQ was tested using CFA. In this study, three hypothesized models, namely: 1-factor model, three-factor model, and higher-order models of the FHBQ were investigated. Analyses were performed using Mplus 8.4. Parameters were estimated using weighted least squares mean and variance-corrected estimator (WLSMV). Several fit indices were used to check the goodness-of-fit of all hypothesized model. The chisquare test was used to evaluate individual models, and the residual mean square root (SRMR) and mean square root approximation error (RMSEA) were used to estimate the lack of fit in the model compared to the baseline model (Shi et al., 2019). The larger the value the greater the specification error, because an RMSEA value less than 0.06 is considered an indication of an adequate fitting model, and values ranged from 0.06-0.08 indicates accepatble RMSEA and a smaller value for SRMR is associated with a better fit model, with a score below 0.08 considered evidence of fit (Wang \& Wang, 2019). Finally, an additional measure of fit index, that is, the comparative fit index (CFI) (Bentler, 1990) is also used. CFI allows comparisons between the specified model and the null model. For CFI, a value of 0.90 is generally considered to indicate an acceptable model (Hu \& Bentler, 1999).

\section{Rating Scale Model (RSM)}

One model of modern test theory, the Polytomous Rasch model of which the dichotomous model is a special case, has been applied to analyse at both the item and the total test score levels (Andrich \& Marais, 2019). Rating Scale Model (RSM; Andrich, 1978) is suitable for assessing polytomous data using a rating scale, as a part of Polytomous Rasch model family. Where applicable, the response rating scale yields ordinal data that needs to be converted to an interval scale to be useful. Rasch RSM generally follows the equation (Luo et al., 2009):

$$
\log \left(\mathrm{P}_{\text {nik }} / \mathrm{P}_{\mathrm{ni}(\mathrm{k}-1)}\right)=\mathrm{B}_{\mathrm{n}}-\mathrm{D}_{\mathrm{i}}-\mathrm{F}_{\mathrm{k}}
$$


Where Pnik is the probability that the nth person passing item i will be "observed" in the k category, $\mathrm{P}_{\mathrm{ni}(\mathrm{k}-\mathrm{l})}$ is the probability that the nth person will choose the $\mathrm{k}-1$ category, $\mathrm{B}_{\mathrm{n}}$ is the trait rate in the measured construct (level of hedonistic behavior) of $\mathrm{n}$-th person, $\mathrm{Di}$ is the item difficulty level of item $\mathrm{i}$ and Fk is the probability that category $\mathrm{k}$ will be selected depending on category $\mathrm{k}-1$ (Luo et al., 2009). In this study, estimates of item difficulty level (Di) and level of social support from respondents (Bn) are expressed on a logit scale. The logit mean is randomly assigned to 0 , with a positive log indicating a higher than average estimate and a negative log lower than the average estimate (Andrich \& Marais, 2019). The threshold indicates the location on the trait level scale where the respondent has a 50/50 chance of choosing a higher category than the current one (Luo et al., 2009; Wright \& Masters, 1982). RSM requires defensible assumptions for accurate estimates, namely: (1) construct unidimensionality, (2) local Independence, and (3) parallel ICCs (Mair, 2018). In addition, the Rasch rating scale model requires that the rating scale categories increase in line with endorsement difficulty, and that the threshold for each item is ordered from low to high (DiStefano \& Morgan, 2010; Linacre, 2010).

In this study, data analysis was performed using the Rasch rating scale model. The software used is the Winsteps to test the validity of the FHBQ instrument. The person and item parameters are estimated using unconditional maximum likelihood estimation (UCON). To obtain information about the psychometric characteristics of the scale, the analysis is reported: (1) To check the unidimensionality expected in the Rasch rating scale model on the Hedonistic Behavior Scale instrument, (2) Testing the local independence assumption using $\mathrm{Q}_{3}$ statistics, (3) Rating Scale Diagnostics testing to determine the functioning of each responses category, (4) Testing fit items with the Rasch model, considering the mean square (MNSQ) statistics when using the Rasch RSM, (5) Reliability testing for person and items , (6) Displays the Wright map and the Test Information Function to compare people and items on the same scale and find out the function of the test when given to individuals with the trait level obtained.

\section{Results and Discussion}

\section{Factor Structure}

Unidimensional, three-factor, and higher-order model fit indices were compared using three separate analyses. The CFA results show that the higher order factor model fits the data quite well $\left[\chi^{2}(74)=\right.$ 170.577, $\mathrm{p}<0.001$; RMSEA $=0.062(90 \% \mathrm{CI}=0.050-0.075), \mathrm{CFI}=0.893, \mathrm{SRMR}=0.052]$ compared to the three-factor model $\left[\chi^{2}(74)=170.576, p<0.000\right.$; $\mathrm{RMSEA}=0.062(90 \% \mathrm{CI}=0.050-0.075)$, CFI $=$ 0.893$, SRMR $=0.052]$ and the unidimensional model $\left[\chi^{2}(77)=194.547, \mathrm{p}<0.001 ; \mathrm{RMSEA}=0.068\right.$ (90\% CI $=0.056-0.079), \mathrm{CFI}=0.870, \mathrm{SRMR}=0.055]$. Thus, the results show that the higher-order model, which consists of three factors, namely: activities, interests, and opinions, and one higher-order factor hedonistic behaviors provides representation of the factor structures underlying the construct of hedonistic behavior.

\section{Unidimensionality}

The first assumption of the Rasch model is the assumption that the construct being measured is unidimensional, a violation of this assumption will cause bias in the estimation of the parameters carried out (Lamprianou, 2019; Smith, 1996). In this study, the assumption of unidimensionality was tested by principal component analysis on the residuals (PCAR; Linacre, 1998). The PCAR analysis results on the FHBQ instrument resulted in a raw variance explained by measure of 12.8 in eigenvalues units and $47.7 \%$ in percentage size. With the criteria that a size of $>40 \%$ (Holster \& Lake, 2016) is sufficient evidence of unidimensionality factor structure, it can be said that the assumption of the unidimensionality of FHBQ in this study is fulfilled. 


\section{Local Independence}

The second assumption from the Rasch model is the local independence assumption. On the assumption of local independence, certain individuals or individuals of the level of ability given, the work on one item does not depend on work on other items (Mair, 2018). The method used to test the local independence assumption is $\mathrm{Q}_{3}$ (Yen, 1984). The results of the analysis of the local independence assumption on the FHBQ are shown in Table 3.

Table 3. Locally Dependent Items Identification

\begin{tabular}{ll}
\hline Raw Residual Correlation & \multicolumn{1}{c}{ Item Pairs } \\
\hline-0.26 & Item 3 and Item 14 \\
-0.24 & Item 11 and Item 13 \\
-0.24 & Item 9 and Item 13 \\
-0.22 & Item 3 and Item 7 \\
-0.20 & Item 2 and Item 4 \\
-0.19 & Item 2 and Item 8 \\
-0.19 & Item 1 and Item 12 \\
-0.19 & Item 8 and Item 12 \\
-0.19 & Item 1 and Item 11 \\
-0.18 & Item 3 and Item 8 \\
\hline
\end{tabular}

In using $\mathrm{Q}_{3}$ statistics, acceptable criteria for locally independence are raw residual correlation between pairs of items is not $>0.20$ (Christensen, Makransky, \& Horton, 2017). As can be seen in Table 3, there are no items that experience local dependence. That is, the pair of items obtained on the female hedonistic behavior scale instrument do not have dependence on each other. It can be concluded, when individuals answer items that describe hedonistic behavior, they do not depend on certain other items as well. The findings can be said that local independence was fulfilled.

\section{Rating Scale Diagnostics}

The rating scale in this study uses a Likert scale. The importance of information regarding the rating scale of an instrument is needed to understand the responses given by respondents who use the rating scale and determine the actual distance that applies to individuals in taking existing response categories (Rahayu et al., 2020). Diagnostics with a rating scale model on the Rasch measurement are used to evaluate how well the response set of the FHBQ serves to create interpretable measures. The 4 (four) rating scale categories in this study are Strongly disagree to strongly agree. The results of the rating scale analysis on the FHBQ are shown in Table 4.

Table 4. Rating Scale Diagnostics of FHBQ

\begin{tabular}{cccccc}
\hline Categories & Threshold & $\begin{array}{c}\text { Observed } \\
\text { Count (\%) }\end{array}$ & $\begin{array}{c}\text { Observed } \\
\text { Average }\end{array}$ & Infit & Outfit \\
\hline Strongly Disagree & None & $467(10 \%)$ & -1.68 & 0.96 & 0.97 \\
Disagree & -2.46 & $1778(38 \%)$ & -0.63 & 0.95 & 0.95 \\
Agree & -0.05 & $1844(39 \%)$ & 0.71 & 0.92 & 0.94 \\
Strongly Agree & 2.52 & $601(13 \%)$ & 2.05 & 1.15 & 1.14 \\
\hline
\end{tabular}

As can be seen in Table 4, the frequency distribution of all categories is in the form of a normal distribution. Then, the information about the threshold is obtained very precisely and well, where the appropriate value of the threshold is obtained monotonically increasing from negative to positive in 
the 4 (four) response categories that used. The conclusion about threshold is further supported by the absence of fit index criteria, namely infit and outfit greater than 2.0 (Linacre, 2010), meaning that the rating scale diagnostics shows the accuracy of the measurement of the responses tested. It can be concluded the findings of the diagnostic rating scale obtained a series of responses to the FHBQ that functioned as expected. Below is evidence of the probability curve of the response category showing the optimal shape in Figure 1.

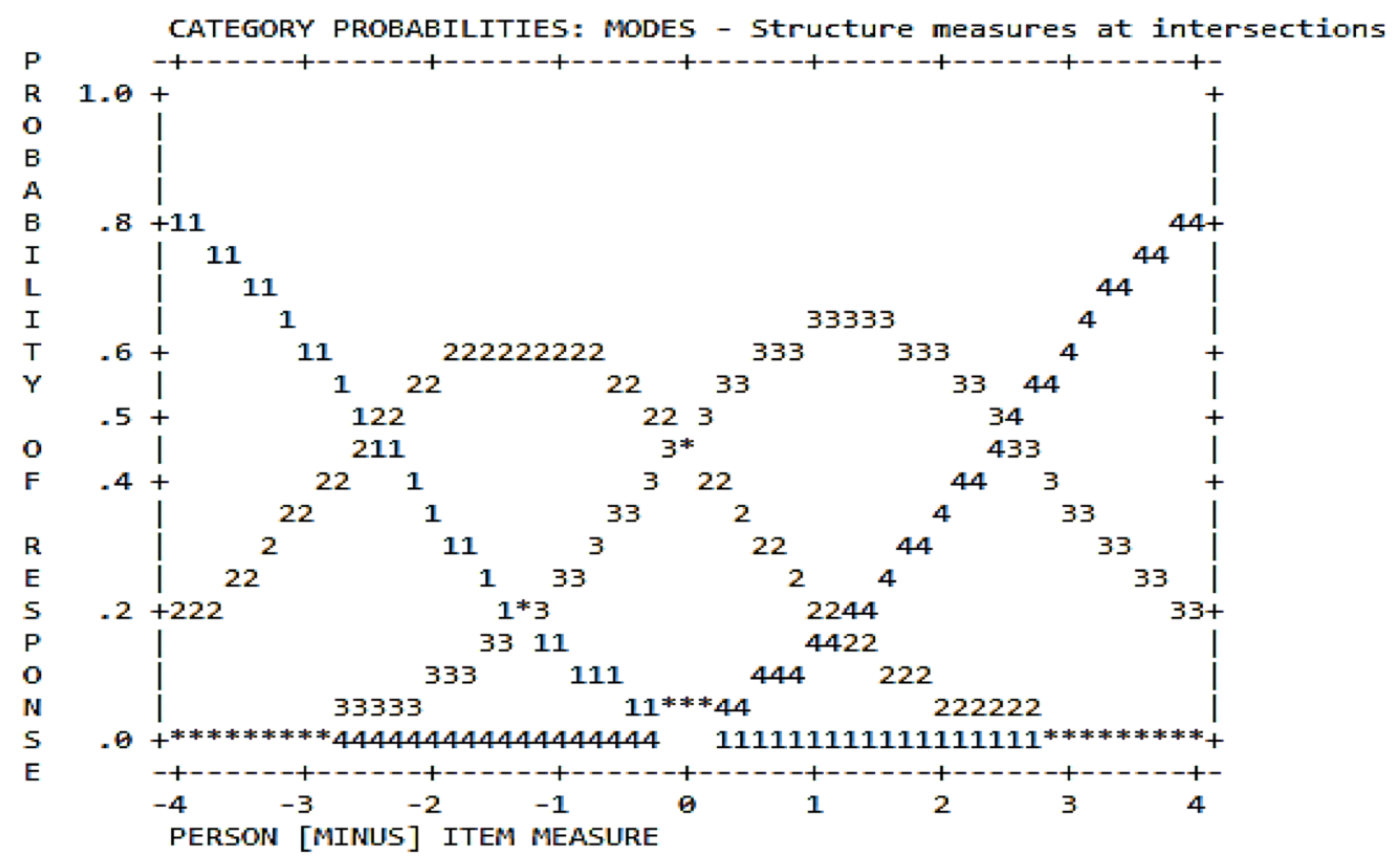

Figure 1. Category Response Curve of FHBQ

This shows that the assumption of equal spacing across items was fulfilled, which means that all the assumptions from the application of RSM are fulfilled. The fulfillment of this assumption shows that the measurement process that has been carried out is no longer disturbed by errors in measurement within an unreasonable limit so that the data that is owned is fit to RSM even into the level of the response category which is very important to be fulfilled.

\section{Item Fit}

Testing fit items such as infit and MNSQ statistical outfit can also be used to determine how well each item measures a construct as evidence that the construct is unidimensional. The MNSQ infit and outfit values are considered fit according to the Rasch rating scale model with a value range of 0.6-1.4 was acceptable (Bond \& Fox, 2015). The results of the analysis on the FBHQ instrument are listed in Table 5. 
Table 5. Rasch Item Location and Fit Statistics of the FHBQ

\begin{tabular}{ccccc}
\hline Item & Measure & Infit MNSQ & Outfit MNSQ & PTMEA \\
\hline 14 & 1.32 & 0.74 & 0.73 & 0.66 \\
7 & 1.17 & 0.96 & 0.96 & 0.51 \\
8 & 0.99 & 0.86 & 0.86 & 0.70 \\
2 & 0.89 & 1.15 & 1.17 & 0.38 \\
10 & 0.70 & 1.15 & 1.15 & 0.54 \\
11 & 0.63 & 0.85 & 0.85 & 0.75 \\
5 & 0.61 & 0.84 & 0.85 & 0.62 \\
9 & 0.44 & 1.01 & 1.03 & 0.58 \\
1 & -0.26 & 0.84 & 0.84 & 0.49 \\
13 & -0.46 & 1.19 & 1.19 & 0.54 \\
12 & -0.66 & 1.18 & 1.17 & 0.55 \\
6 & -1.25 & 0.97 & 0.98 & 0.54 \\
3 & -1.78 & 1.23 & 1.22 & 0.41 \\
4 & -2.35 & 0.93 & 0.94 & 0.43 \\
\hline
\end{tabular}

In Table 5, it can be seen that the items have been sorted from the items that are the most difficult (item 14 , measure $=1.32$ ) to be approved and the items that are easiest to endorsed (item 4 , measure $=$ -2.35). The results show that all items on the Female Hedonistic Behavior Questionnaire instrument are declared fit to measure hedonistic behavior in Muslim women wearing hijab. With the criteria for the fit rasch model index, namely the statistics infit and outfit in the range of $0.6-1.4$, in this study 14 items measuring hedonistic behavior can be said to be fit with the Rasch measurement model.

\section{Person and Item Separation Reliability}

In the Rasch model, reliability is not the same concept as in the classical approach, reliability is estimated for either person or item (Wright \& Masters, 1982). Person reliability is an estimate of how well this instrument can distinguish respondents regarding the measured variable where the result is 0.81 . Meanwhile, the person separation index is an estimate of the distribution of respondents where the value is 2.01 . Item reliability and item separation index are 0.99 and 11.93 , respectively. These findings indicate that the psychometric characteristics of the FHBQ were obtained very precisely. The separation index criteria of 1.5 are sufficient (Tennant \& Conaghan, 2007), and these criteria have been met in this study.

\section{Wright Map and Test Information Function}

The Rasch rating scale model determines the validity of the construct according to the hierarchy of items that can be observed in the Wright map (Pichardo et al., 2018). This map illustrates the difficulty item on the right and the ability person on the left. Items must form a continuum scale with items with low difficulty at the bottom, and items with the mean of item difficulty in the middle (denotes by $\mathrm{M}$ on the right side), and items with highest measure at the top. Persons are distributed in the same way, according to the level of attributes in the measured variable, in this study the hedonistic behavior construct. The Wright map of the results of the FHBQ instrument analysis can be seen in Figure 2. 


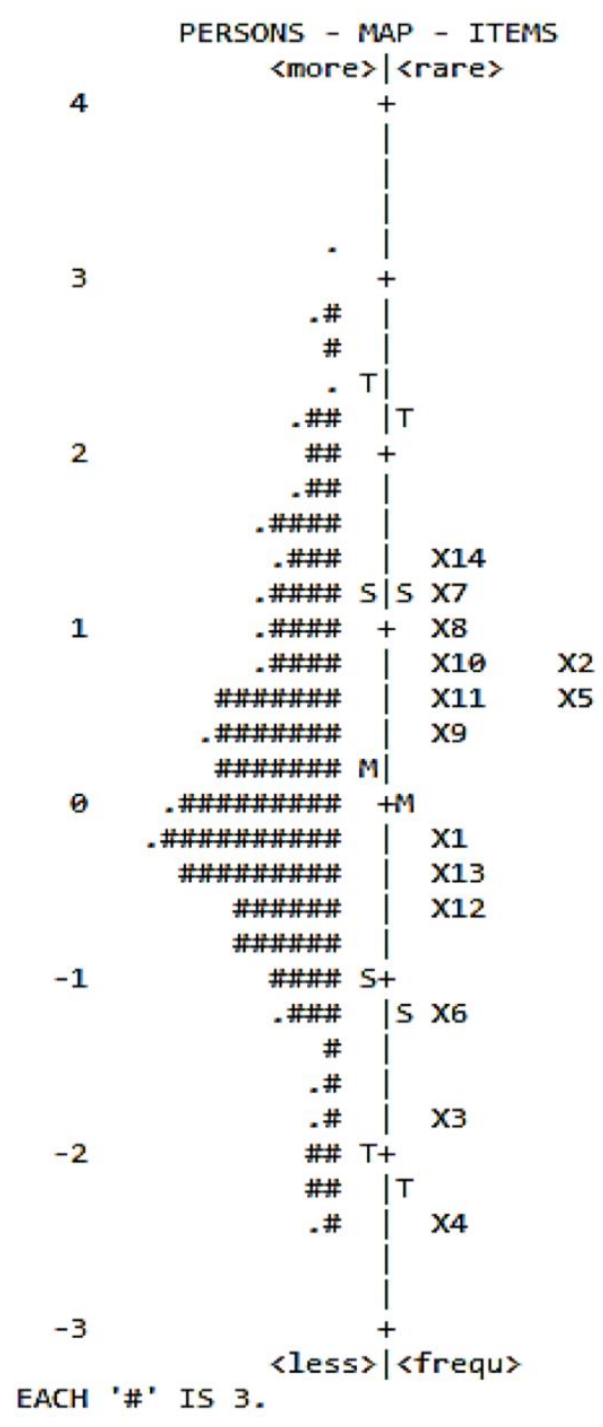

Figure 2. Wright Map of Female Hedonistic Behavior Questionnaire

It can be seen in Figure 2, it is clear that the item difficulty level is the most difficult to agree on is item 14 "Uang yang saya miliki dihabiskan untuk bersenang-senang", and item difficulty level that is easy to agree on is item 4 "Saya tertarik pergi ke tempat yang belum saya kunjungi untuk bersenang-senang". The average value of a person's measure is 0.14 logit (standard deviation $[\mathrm{SD}])=1.09$ ), indicating that the average measure of Muslim women wearing hijabs to have hedonistic behavior is higher than the average level of item measure (location) is zero. In addition, the distribution of people ranges from 3.17 to -2.35 , which is greater than the distribution of items ranging from 1.32 to -2.35 .

In addition to the information above, information is also generated in the form of a test information function (TIF) in Figure 3 which shows the function of the test when it is given to individuals with the level of traits obtained. Trait in question is an item that measures the construct of social support that individuals get tends to be low, medium, or up to high. The better the item targeted at people, the more information Fisher the item provided about the parameters of the person. The test information function is expected to peak, where a reference to the test criteria tested will be obtained, and where the sample test reference model shows normal. With this, TIF is an effective test measurement range (Linacre, 2018). 


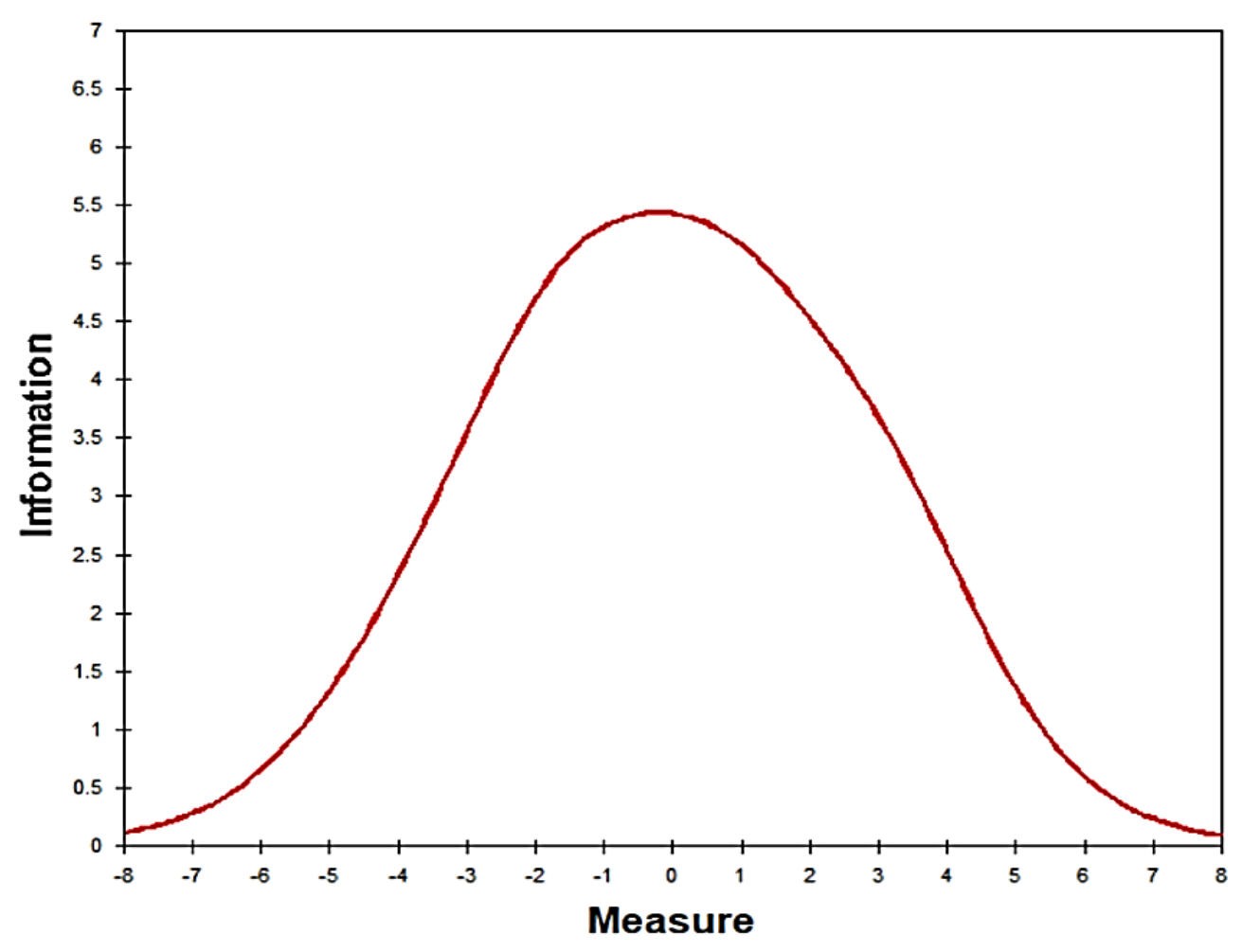

Figure 3. Test Information Function of FHBQ

As can be seen in the Figure 3, along the trait range of -1.00 to +1.00 logit the amount of information from the test is greater than 5 with the highest information peak at the hedonistic behavior trait level of around 0 , that this instrument is an excellent and optimal measuring tool. To measure respondents who are in the very low to average trait range, when the position is very high $(+3)$ and very low $(-3)$ it will be said that the accuracy of the test has decreased. This means that information about tests on a set of items that measure the construct of hedonistic behavior is very precise and optimal for people who have relatively moderate abilities.

\section{Discussion}

This study aims to develop instruments of a hedonistic lifestyle (Wells \& Tigert, 1971) using modern test theory, such as the Rasch measurement model that has never been used by many researchers in Indonesia (see, Hayat et al., 2020). The results of the Rasch rating scale model analysis obtained show that the three-aspect hedonistic lifestyle instrument is proven to have a unidimensional factor structure. The finding is interesting that there are no items that measure anything other than theorized hedonistic behavior, specifically for Muslim women who wear hijab. Interestingly, all items from the hedonistic lifestyle have fulfilled the local independence assumption very well. When individuals answer items that describe hedonistic behavior, they do not depend on certain other items either. The results of separation and reliability indicies for people and items fall into the very good category. Even a perfect unidimensional scale will not be of practical use if the resulting scale scores have very low reliability (Gerbing \& Anderson, 1988). The findings regarding the wright map show that the average chance of Muslim women wearing hijab in this study has a high hedonistic behavior compared to the items tested. Therefore, it can be completed that the test information function in this study is very precise and optimal for people who have relatively moderate abilities in the Rasch rating scale model analysis. 
The limitations of this study are the use of samples in one particular area. Further research is suggested to test the instrument validity of the three aspects of the hedonistic lifestyle in various regions of Indonesia to see hijab-wearing Muslim women with more visible behavioral tendencies from the items that used, and can even be tested with other sample characteristics in order to conclude in a larger and more heterogeneous population. However, the use of the Rasch rating scale model analysis has provided a solution in testing the validity of the construct of hedonistic behavior from three aspects of the hedonistic lifestyle, because the methodology used does not depend on the sampling involved, and the psychometric tests carried out in this study have perfected previous studies.

\section{Conclusion}

This study can be concluded that the instrument derived from three aspects of hedonistic lifestyle from Well and Tigert in Engel 1996 in this study can be used and utilized properly for researchers, practitioners, and students in the field of psychological research and behavioral science in conducting further research. Especially those who need an instrument to measure hedonistic behavior in Muslim women wearing hijab. With this, the measuring tool developed by the researcher is named the Female Hedonistic Behavior Questionnaire with 14 valid items from the Rasch rating scale model measurement model perspective.

\section{References}

Andrich, D. (1978). A rating formulation for ordered response categories. Psychometrika, 43(4), 561-573. https://doi.org/10.1007/BF02293814

Andrich, D., \& Marais, I. (2019). A course in rasch measurement theory: Measuring in the educational, social and health sciences. Singapore: Springer Nature Singapore Pte. Ltd. https://doi.org/10.1007/978-98113-7496-8

Bentler, P. M. (1990). Comparative fit indexes in structural models. Psychological Bulletin, 107(2), 238246. https://doi.org/10.1037/0033-2909.107.2.238

Bond, T., \& Fox, C. (2015). Applying the Rasch model: Fundamental measurement in the human sciences (3rd ed.). New York, NY: Routledge. https://doi.org/10.4324/9781315814698

Chou, Y.-T., \& Wang, W.-C. (2010). Checking dimensionality in item response models with principal component analysis on standardized residuals. Educational and Psychological Measurement, 70(5), 717-731. https://doi.org/10.1177/0013164410379322

Christensen, K. B., Makransky, G., \& Horton, M. (2017). Critical values for Yen's Q3: Identification of local dependence in the Rasch model using residual correlations. Applied Psychological Measurement, 41(3), 178-194. https://doi.org/10.1177/0146621616677520

DiStefano, C., \& Morgan, G. B. (2010). Evaluation of the BESS TRS-CA using the Rasch rating scale model. School Psychology Quarterly, 25(4), 202-212. https://doi.org/10.1037/a0021509

Flora, D. B., \& Curran, P. J. (2004). An empirical evaluation of alternative methods of estimation for confirmatory factor analysis with ordinal data. Psychological Methods, 9(4), 466-491. https://doi.org/10.1037/1082-989X.9.4.466

Gerbing, D. W., \& Anderson, J. C. (1988). An updated paradigm for scale development incorporating unidimensionality and its assessment. Journal of Marketing Research, 25(2), 186-192. https://doi.org/10.1177/002224378802500207

Gulamhussein, Q., \& Eaton, N. R. (2015). Hijab, religiosity, and psychological well-being of muslim women in the United States. Journal of Muslim Mental Health, 9(2), 25-40. https://doi.org/10.3998/jmmh.10381607.0009.202 
Hamzah, S. R., Krauss, S., Suandi, T., Hamzah, A., \& Tamam, E. (2013). The influence of religiosity, parental and peer attachment on hedonistic behavior among Malaysian youth. Procedia-Social and Behavioral Sciences, 122, 393-397. https://doi.org/10.1016/j.sbspro.2014.01.1360

Hamzah, S. R., Suandi, T., Krauss, S. E., Hamzah, A. \& Tamam, E. (2014). Youth hedonistic behaviour: moderating role of peer attachment on the effect of religiosity and worldview. International Journal of Adolescence and Youth, 19(4), 419-433. https://doi.org/10.1080/02673843.2014.942793

Hayat, B., Putra, M. D. K., \& Suryadi, B. (2020). Comparing item parameter estimates and fit statistics of the Rasch model from three different traditions. Jurnal Penelitian dan Evaluasi Pendidikan, 24(1). https://doi.org/10.21831/pep.v24i1.29871

Higgins (1997). Beyond pleasure and pain. American Psychologist, 52(12), 1280-1300. https://doi.org/10.1037/0003-066X.52.12.1280

Holster, T. A., \& Lake, J. (2016). Guessing and the Rasch model. Language Assessment Quarterly, 13(2), 124-141. https://doi.org/10.1080/15434303.2016.1160096

Hu, L.-T., \& Bentler, P. M. (1999). Cutoff criteria for fit indexes in covariance structure analysis: Conventional criteria versus new alternatives. Structural Equation Modeling, 6(1), 1-55. https://doi.org/10.1080/10705519909540118

Kunzmann, U., Stange, A., \& Jordan, J. (2005). Positive affectivity and lifestyle in adulthood: do you do what you feel? Personality and Social Psychology Bulletin, 31(4), 574-588. https://doi.org/10.1177/0146167204271586

Lamprianou, I. (2019). Applying the Rasch model in social sciences using R. New York, NY: Routledge. https://doi.org/10.4324/9781315146850

Linacre, J. M. (1998). Detecting multidimensionality: Which residual data-type works best? Journal of Outcome Measurement, 2(3), 266-283.

Linacre, J. M. (2010). Predicting responses from Rasch measures. Journal of Applied Measurement, 11(1), $1-10$.

Luo, X., Cappelleri, J. C., Cella, D., Li, J. Z., Charbonneau, C., Kim, S. T., \& Motzer, R. J. (2009). Using the Rasch model to validate and enhance the interpretation of the functional assessment of cancer therapy-kidney symptom index-disease-related symptoms scale. Value in Health, 12(4), 580 586. https://doi.org/10.1111/j.1524-4733.2008.00473.x

Mair, P. (2018). Modern psychometrics with $R$. Cham, Switzerland: Springer International Publishing AG. https://doi.org/10.1007/978-3-319-93177-7

Masters, G. N., \& Wright, B. D. (1984). The essential process in a family of measurement models. Psychometrika, 49(4), 529-544. https://doi.org/10.1007/BF02302590

Peterson, C., Park, N., \& Seligman, M.E. (2005). Orientations to happiness and life satisfaction: The full life versus the empty life. Journal of Happiness Studies, 6(1), 25-41. https://doi.org/10.1007/s10902004-1278-z

Pichardo M. C., Cano, F., Garzon-Umerenkova, A., de la Fuente, J., Peralta-Sanchezm F. J., \& AmateRomera, J. (2018). Self Regulation Questionnaire (SRQ) in Spanish adolescents: Factor structure and Rasch analysis. Frontiers in Psychology, 9: 1370. https://doi.org/10.3389/fpsyg.2018.01370

Rahayu, W., Putra, M. D. K.,

Rofhani, R. (2017). Ekspresi dan representasi budaya perempuan Muslim kelas menengah di Surabaya. Islamica: Jurnal Studi Keislaman, 11(2), 277-310. https://doi.org/10.15642/islamica.2017.11.2.277310

Saputri. A., \& Rachmatan. R. (2016). Religiusitas dengan gaya hidup hedonisme: Sebuah gambaran pada mahasiswa Universitas Syiah Kuala. Jurnal Psikologi, 12(2), 59-67. http://dx.doi.org/10.24014/jp.v12i2.3230 
Shi, D., Lee, T., \& Maydeu-Olivares, A. (2019). Understanding the model size effect on SEM fit indices. $\begin{array}{llll}\text { Educational and Psychological } & \text { Measurement, }\end{array}$ https://doi.org/10.1177/0013164418783530

Sholeh, A. (2017). The relationship among hedonistic lifestyle, life satisfaction, and happiness on college students. International Journal of Social Science and Humanity, 7(9), 604-607. https://doi.org/10.18178/ijssh.2017.7.9.892

Smith, R. M. (1996). A comparison of methods for determining dimensionality in Rasch measurement. Structural Equation Modeling: A Multidisciplinary Journal, 3(1), 25-40. https://doi.org/10.1080/10705519609540027

Sobol-Kwapinska, M. (2013). Hedonism, fatalism and 'carpe diem': Profiles of attitudes towards the present time. Time \& Society, 22(3), 371-390. https://doi.org/10.1177/0961463X13487043

Teo, C. B. C., \& Sidin S. M. (2014). Development and validation of Female Hedonic Orientation Scale. Procedia - Social and Behavioral Sciences, 130, 390-399. https://doi.org/10.1016/j.sbspro.2014.04.046

Tennant, A., \& Conaghan, P. G. (2007). The Rasch measurement model in rheumatology: What is it and why use it? When should it be applied, and what should one look for in a Rasch paper? Arthritis Care and Research, 5(8), 1358-1362. https://doi.org/10.1002/art.23108

VandenBos, G. R. (2015). APA dictionary of psychology (2nd ed.). Washington, DC: American Psychological Association

Wells, W. D., \& Tigert, D. (1971). Activities, interests, and, opinions. Journal of Advertising Research, 11(4), 27-35.

Wright, B. D., \& Masters, G. N. (1982). Rating scale analysis. Chicago, IL: MESA Press.

Yen, W. M. (1984). Effects of local item dependence on the fit and equating performance of the threeparameter logistic model. Applied Psychological Measurement, 8(2), 125-145. https://doi.org/10.1177/014662168400800201 